\title{
Etisk kompetanseheving i norske kommuner-hva er gjort, og hva har vært levedyktig over tid?
}

\section{Elisabeth Gjerberg ${ }^{1}$, Lillian Lillemoen ${ }^{2}$, Anne Dreyer $^{3}$, Reidar Pedersen $^{4} \&$ Reidun Forde ${ }^{5}$}

${ }^{1}$ Senter for medisinsk etikk, Institutt for helse og samfunn, Det medisinske fakultet, Universitetet i Oslo

elisabeth.gjerberg@medisin.uio.no

${ }^{2}$ Senter for medisinsk etikk, Institutt for helse og samfunn, Det medisinske fakultet, Universitetet i Oslo

lillian.lillemoen@medisin.uio.no

${ }^{3}$ Diakonhjemmet sykehus

anne.dreyer@diakonsyk.no

${ }^{4}$ Senter for medisinsk etikk, Institutt for helse og samfunn, Det medisinske fakultet, Universitetet i Oslo

reidar.pedersen@medisin.uio.no

${ }^{5}$ Senter for medisinsk etikk, Institutt for helse og samfunn, Det medisinske fakultet, Universitetet i Oslo

reidun.forde@medisin.uio.no

De senere år har pleie- og omsorgstjenesten $i$ mange norske kommuner startet med ulike former for etikkarbeid, oftest initiert av KS' prosjekt "Samarbeid om etisk kompetanseheving”. Hensikten med vår studie var å evaluere innsatsen $i$ de kommunene som deltok $i$ prosjektet fra starten av, med vekt på hvilke tiltak som var iverksatt, hvilke virksomheter dette omfattet, og om tiltakene har fortsatt utover prosjektperioden. Studien har et kvalitativt design. Materialet er hovedsakelig basert på telefonintervjuer med kontaktpersoner for etikksatsingen i 34 kommuner. Det transkriberte materialet er analysert ved kvalitativ innholdsanalyse. Med unntak av fem kommuner som aldri kom i gang med etikkarbeidet, hadde de fleste startet etikkrefleksjon innenfor flere tjenester, oftest i sykehjem og hjemmetjenester. Noen kommuner hadde imidlertid ikke klart å videreføre etikkarbeidet utover en prosjektperiode. Det var stor variasjon både i etikkarbeidets forankring $i$ kommunen, omfang, hyppighet og metoder. Et gjennomgående funn er vektlegging av behovet for etikkkompetanse og oppfølging av dem som skal lede etikkarbeidet. Flertallet av kommunene som fortsatt gjennomfører etikkrefleksjon, tar utgangspunkt $i$ egen praksis, men et mindretall anvender strukturerte metoder. Dersom etikkarbeidet $i$ kommunen skal vore levedyktig over tid, bør arbeidet forankres på flere nivår i organisasjonen, og de som skal lede dette arbeidet, bør få styrket sin kompetanse i etikk og etikkrefleksjon.

Nøkkelord: etikk, evaluering, kommunehelsetjenesten 
English summary: Building ethical competence in Norwegian municipalities: What has been done and what has been sustainable?

"Cooperation for building ethics competence" is a national project aimed to stimulate moral reflection and build competence in ethics in community health services in Norway. This article is based on an evaluation of the activities implemented by the first 34 participating municipalities, exploring which measures were implemented, which services and employees were involved, and if the measures are sustainable. The study has a qualitative design, and the data mainly consists of telephone interviews with "key" persons in 34 municipalities. With the exception of five municipalities that never really started ethics work, the majority had implemented ethical reflection in several areas, most often in nursing homes and home care services. There was great variation with regard to the implementation (organisation of reflection groups, how much time, and methods used). Many had tried a variety of reflection models, and only a minority of the municipalities were using a structured method of ethical reflection. A consistent finding is the need for more competence; many of those who run ethical reflection are reported to need more competence both in ethics and methods for systematic reflection. There were also great variations in how well the ethics projects were anchored within the municipality. To make ethical interventions sustainable, this study indicates the importance of strong anchoring within the municipality, the need for ethical competence, as well as good methods for structuring ethical reflection.

Keywords: community health services, ethics, evaluation, qualitative method, reflection

\section{Innledning}

Prosjektet "Samarbeid om etisk kompetanseheving i kommunene" er en stor satsing i regi av kommunesektorens arbeidsgiver- og interesseorganisasjon KS i samarbeid med Helseog omsorgsdepartementet (HOD), arbeidstakerorganisasjonene i pleie- og omsorgstjenesten og Helsedirektoratet. Formålet med prosjektet er å styrke den etiske kompetansen i kommunenes helse-, sosial- og omsorgstjenester, herunder etablering av systematisk etikkrefleksjon. Prosjektet startet i 2007 og hadde ved årsskiftet 2013/2014 rekruttert 213 kommuner, fordelt på seks puljer, inn i prosjektet. Prosjektet skal avsluttes i 2015.

I 2011 gjennomførte Senter for medisinsk etikk ved Universitetet i Oslo en evaluering av etikksatsingen i de kommunene som kom tidlig med i prosjektet. Denne artikkelen presenterer resultatene fra evalueringen.

Hensikten med studien er å evaluere etikksatsingen i de kommunene som deltok i KSprosjektet fra starten av. Vi ønsket kunnskap om hva slags tiltak som var iverksatt, hvilke tjenestesteder og ansatte innen helse- og omsorgstjenesten dette omfattet, og hvordan arbeidet var forankret og organisert i kommunene. Vi var også opptatt av om etikksatsingen hadde fortsatt utover en innledende prosjektperiode, og om det var mulig å finne fram til faktorer som synes å påvirke dette. Har for eksempel organisatorisk forankring, organisering av etikkarbeidet, kompetanse i etikk og metoder for refleksjon betydning for hvorvidt kommunene har klart å etablere og vedlikeholde systematisk etikkarbeid? 


\section{Bakgrunn}

Satsingen på etisk kompetanseheving inngår som en del av helse- og omsorgsmyndighetenes strategi for å styrke kompetansen i omsorgstjenesten, der kommunene oppfordres til å sørge for at ansatte får opplæring i etiske prinsipper for yrkesutøvelsen (Det kongelige helse- og omsorgsdepartement 2006). En viktig begrunnelse for satsingen er at ansatte i helse- og omsorgstjenestene daglig står overfor mange komplekse etiske utfordringer som krever etisk bevissthet og dømmekraft, problemstillinger det kan være vanskelig å mestre. Gjennom flere år har Helsetilsynets årlige tilsynsmeldinger beskrevet situasjoner der sykehjemspasienter ikke har fått forsvarlig og omsorgsfull hjelp, forårsaket av personalets mangelfulle håndtering, se for eksempel Tilsynsmelding 2010 (Statens Helsetilsyn 2010). Også flere norske studier beskriver etiske utfordringer i sykehjem og hvordan personalet håndterer disse (Bollig et al. 2009; Gjerberg et al. 2010; Lillemoen \& Pedersen 2013; Slettebo \& Bunch 2004; Solum et al. 2008). Etiske dilemmaer knyttet til ressursmangel synes oftest forekommende, men også bruk av tvang, samarbeid med pårørende og beslutninger rundt livets avslutning kan innebære etiske utfordringer. Flere studier peker på et stort behov for å styrke ansattes etiske kompetanse og for tid til å diskutere etiske utfordringer i arbeidet (Forde \& Aasland 2013; Gjerberg et al. 2010; Lillemoen \& Pedersen 2013; Soderhamn et al. 2014). Dårlig håndtering av etiske dilemmaer kan medføre utbrenthet og moralsk stress blant ansatte (Kalvemark et al. 2004; McCarthy \& Deady 2008), og bedret etisk kompetanse vil således kunne komme både brukere og ansatte til gode.

\section{Etikksatsingen i kommunehelsetjenesten}

Norske sykehus er pålagt å ha kliniske etikk-komiteer, som skal bidra til å høyne etisk bevissthet og kvalitetssikre vanskelige etiske beslutninger til det beste for pasienter, pårørende og helsepersonell (Senter for medisinsk etikk 2011). Den kommunale pleie- og omsorgstjenesten har ingen slike pålegg utover de føringer som ligger i stortingsmelding nr. 25 (2005-2006) (Det kongelige helse- og omsorgsdepartement 2006). Her oppfordres kommunene til å sørge for at ansatte i omsorgstjenesten får opplæring i etikk, og at denne opplæringen blir vedlikeholdt og oppdatert gjennom undervisning og veiledning. Stortingsmeldingen peker på at etiske holdninger og handlinger utvikles gjennom løpende utprøving og refleksjon i praktisk arbeid og oppfordrer kommunene å legge til rette for å gi ansatte i den kommunale omsorgstjenesten bedre rom for etisk refleksjon i det daglige arbeidet. Det var nettopp for å styrke den etiske kompetansen i omsorgstjenesten at samarbeidet mellom HOD, KS og yrkesorganisasjonene ble etablert. Ifølge et notat fra KS til HOD fra 2007 (KS 2007) er prosjektets tre hovedmål:

1 Utvikle modeller for å etablere arenaer der etiske dilemmaer kan behandles og råd kan gis i konkrete saker.

2 Utvikle opplæringsprogram med sikte på at alle ansatte får tilbud om grunnleggende opplæring i praksisrelatert etikk.

3 Stimulere kommunene til å etablere arenaer for systematisk refleksjon. 
Opplæringstilbud fra KS: KS-prosjektet startet høsten 2007 med en idékonferanse med åtte «ressurskommuner», det vil si kommuner som allerede var i gang med etikkarbeid. Våren 2008 ble disse invitert til en konferanse om etiske utfordringer, et seminar i prosessveiledning for å lede etisk refleksjon og en nettverkssamling. Samtidig ble den første puljen av nye kommuner (i alt 27 kommuner) rekruttert til prosjektet med tilbud om følgende opplæringsressurser:

- Oppstartkonferanse: et todagers seminar, der målet var faglig påfyll, motivasjon og inspirasjon til å iverksette tiltak i egen kommune.

- Etikkhåndboka (Eide \& Aadland 2008): en bok om etikkarbeid i kommunenes helseog omsorgstjenester med vekt på etikk som systematisk refleksjon. Ulike metoder og tiltak for etisk refleksjon blir presentert i boken, for eksempel:

- Basismodeller: «Etisk refleksjonsmodell» - strukturerte diskursetiske modeller som benyttes i drøfting av konkrete etiske utfordringer.

- Lavterskeltiltak: «Trekk et kort» - en samling refleksjonskort med utsagn, beskrivelse av holdninger eller vanskelige situasjoner en kan reflektere rundt.

- Nordpå-kurset: et tredagerskurs i metoder og verktøy for etisk refleksjon. Deltakerne fikk blant annet opplæring i sekvensiell samtale («fishbowl»-metoden $)^{1}$ - en styrt samtale der det den ene sier, gir grunnlag for neste persons uttrykte tanke.

Målgruppen for disse opplæringstiltakene var personer som var tiltenkt en sentral rolle i etikkarbeidet lokalt. Prosjektet var en stor satsing fra KS' side; i januar 2013 ble 3,2 stillinger brukt til arrangement av konferanser, kurs og oppfølging av kommuner over hele landet (KS 2014a).

\section{Hva sier tidligere studier om nytten av systematisk etikkarbeid?}

Det er de senere årene foretatt flere evalueringer av etikkarbeid i sykehusene (Forde \& Vandvik 2005; Kalager et al. 2011; Molewijk et al. 2008; Pedersen et al. 2007; Schneiderman et al. 2003) som tyder på at dette arbeidet oppleves nyttig av involverte parter og bedrer deres etiske kompetanse (Kalager et al. 2011; Molewijk et al. 2008; Schneiderman et al. 2003).

En tidligere litteraturgjennomgang viste at det fram til 2008 var sparsomt med systematisk evaluering av etikktiltak i kommunehelsetjenesten (Bollig et al. 2009). Vi oppdaterte derfor Bollig og medarbeideres litteratursøk i PubMed og Cinahl med relevante søkeord for temaene etikk, kommunehelsetjeneste og empiriske studier. Søket var rettet mot studier av måter å håndtere etiske utfordringer på i kommunehelsetjenesten, for eksempel gjennom etikk-komiteer, refleksjonsgrupper, etikkveiledning etc. Vi vurderte sammendrag fra 317 artikler. Av disse ble 21 innhentet i fulltekst og to studier identifisert på andre måter. Syv artikler samt en rapport ble inkludert (Børslett et al. 2011; Brown et al. 1987; Glasser et al. 1988; Osborne et al. 2000; Schick \& Moore 1998; Thompson \& Thompson 1990; van der Dam et al. 2011; Weston et al. 2005). 
Litteraturen beskriver i hovedsak etikk-komiteers arbeid i sykehjem (Brown et al. 1987; Glasser et al. 1988; Osborne et al. 2000; Thompson \& Thompson 1990; Weston et al. 2005) med vekt på tre oppgaver: drøfting av konkrete caser, opplæring av personalet og utforming av retningslinjer. To studier evaluerte erfaringer med refleksjonsgrupper $\mathrm{i}$ kommunehelsetjenesten (Børslett et al. 2011; van der Dam et al. 2011). Disse viser at deltakerne opplevde at refleksjonsarbeidet blant annet bidro til større forståelse for andres perspektiv, mer uformell kommunikasjon om etiske spørsmål og flere og bedre løsninger. Slike funn bekreftes også i en nylig publisert studie fra Norge, der ansatte i kommunehelsetjenesten gir uttrykk for at etikkrefleksjon bidro til større oppmerksomhet om etiske utfordringer og større forståelse for både pasienter og kollegaer (Soderhamn et al. 2014).

\section{Teoretisk referanseramme}

Når en skal belyse hvordan etikksatsingen er gjennomført i ulike kommuner, kan tidligere studier og modeller for hvordan ulike kvalitetsforbedrende tiltak bør innføres i helsetjenesten, gi nyttig innsikt. For eksempel beskriver flere studier problemer med å implementere kunnskapsbasert praksis (Forsetlund et al. 2009; Gale \& Schaffer 2009). Selv om ansatte har en positiv innstilling, viser studier at det ikke er tilstrekkelig (Snibsøer et al. 2012). Dette peker på behov for å undersøke hvilke strategier som er mest effektive, og de senere års syntetisering av erfaringer med implementering av ny kunnskap i helsetjenesten kan også ha overføringsverdi til andre kvalitetsforbedringstiltak, som for eksempel etikksatsingen i kommunene. Studier peker blant annet på at den organisatoriske strukturen må tilrettelegges, lokale barrierer for implementering kartlegges, ansatte tilføres kompetanse og både ledelse og ansatte involveres i prosessen (Foxcroft \& Cole 2003; Sandvik et al. 2011).

Det foreligger nå et bredt spekter av litteratur med teorier om spredning av kvalitetsforbedring og innovasjon i helsetjenesten. På tross av noe forskjellig vinkling synes de fleste å fremheve behovet for å trekke inn flere teoretiske perspektiv på tvers av disipliner, ikke minst fordi implementering ofte berører både individ, gruppe, organisasjon og sosialt system (Eccles et al. 2005). Kitson (2009) hevder at det nå er en begynnende erkjennelse av at kunnskapsoverføring er nødvendig, men ikke tilstrekkelig, og at det er viktig å se på organisasjonen som et system av gjensidige relasjoner der teorier om hva som skaper lærende organisasjoner, er sentralt (Schön 1987; Senge 1990). Helsetjenesten kan best sees som en kompleks, organisk enhet, der refleksjon og erfaringslæring både på individuelt og kollektivt nivå er viktig for å skape en kultur for kvalitetsforbedring. I tråd med dette kan etikkprosjektet sees som et kvalitetsforbedringsprosjekt, der organisatorisk læring er en forutsetning for å lykkes. Den lokale konteksten spiller en vesentlig rolle, der organisasjonskultur, ledelse, metoder for endringsarbeid og evaluering står sentralt $\mathrm{i}$ gjennomføringen av tiltak (McCormack et al. 2002). For å lykkes må miljøet være positivt til å ta i bruk nye tiltak, aktører på ulike nivåer må involveres i implementeringsprosessen, og ledelsen må legge til rette for læring. Dette er erfaringer som trolig også er av relevans i prosjekter der en sikter mot å bedre ansattes etiske kompetanse. 


\section{Design, materiale og metode}

Studien har et kvalitativt, deskriptivt design, der vi benyttet telefonintervju med informantene, basert på en semistrukturert intervjuguide. ${ }^{2}$

\section{Utvalg/informanter}

For å samle erfaringer fra dem som hadde arbeidet lengst med etisk kompetanseheving i kommunene, besluttet vi i samråd med KS å konsentrere oss om ressurskommunene (åtte kommuner) og kommunene fra pulje 1 (27 kommuner). Med bakgrunn i prosjektets problemstilling ønsket vi kontakt med informanter som kunne tenkes å ha oversikt over hvilke tiltak som var iverksatt i kommunen, hvordan tiltakene var organisert, samt mest mulig informasjon om hvordan etikkarbeidet ble drevet rundt om på lokale arbeidsplasser. KS anbefalte oss å intervjue såkalte kontaktpersoner for etikksatsingen i disse kommunene, da disse var antatt å ha mest erfaring fra eller kjennskap til prosjektet som helhet.

Én av kommunene var representert både blant ressurskommunene og i pulje 1 med to ulike etikkprosjekt, det vil si at det var til sammen 35 mulige kontaktpersoner/informanter fordelt på 34 kommuner. Kommunene hadde god geografisk spredning fra nord til sør.

Informasjon om studien ble sendt kontaktpersonene på e-post med forespørsel om telefonintervju, og med spørsmål om alternative kontaktpersoner dersom vedkommende selv ikke lenger var kontaktperson for prosjektet. Fire personer hadde sluttet eller gått over i en annen funksjon. Her var det oppnevnt nye kontaktpersoner som ikke hadde fulgt etikksatsingen fra starten.

De fleste kontaktpersonene hadde en lederrolle innen pleie- og omsorgssektoren, for eksempel som enhetsleder, faglig leder eller prosjektleder.

Trettitre informanter svarte på henvendelsen ved å oppgi tidspunkt for et telefonintervju. For to kommuner valgte vi å basere oss på skriftlig evaluering og andre kilder. Fra en av disse to kommunene hadde vi detaljkunnskap fra etikkarbeidet fordi en av forskerne hadde vært involvert i kommunens etikkprosjekt. Den andre kommunen var på samme tid involvert i en annen evaluering av etikkarbeidet, og for ikke å belaste dem med ytterligere et prosjekt valgte vi her å basere oss på skriftlig dokumentasjon om prosjektet. Dette betyr at data fra samtlige prosjekt i ressurskommunene og pulje 1 ble inkludert.

\section{Datainnsamling}

Semistrukturerte intervju (Kvale et al. 2009) ble gjennomført på telefon og nedskrevet direkte. Telefonintervju ble valgt i stedet for spørreskjema fordi det i større grad gir mulighet for oppfølgingsspørsmål avhengig av hva respondentene svarer. Intervjuguiden omfattet hovedsakelig åpne spørsmål, knyttet til følgende temaer: Hvilke tiltak var iverksatt? Hvilke tjenestesteder og ansatte omfattet tiltakene? Var tiltakene fortsatt virksomme? Hvordan var refleksjonsarbeidet organisert, og hvilke metoder ble brukt i arbeidet? Utover dette stilte vi spørsmål om etikkprosjektets forankring og ressursinnsats, 
inklusiv kompetansehevende tiltak, eventuelle hindringer i gjennomføringen av prosjektet samt om det var gjennomført noen form for evaluering. Intervjuene varte fra 30 til 60 minutter.

\section{Dataanalyse}

Samtalene ble nedskrevet under og rett i etterkant av intervjuene, og det er denne teksten som danner grunnlag for analysen. Analysearbeidet foregikk i flere faser. Alle forfatterne leste utskriftene både underveis i prosessen og avslutningsvis. Dette ga oss en felles forståelse av både helheten i materialet og sentrale temaer og en innledende strukturering av dataene med utgangspunkt i de spørsmålene vi stilte. Fokus for analysen var hva materialet fortalte oss om etikkarbeidet - hvordan etikkarbeidet var iverksatt, type etikkarbeid og om spesielle forhold synes å ha influert på etablering og vedlikehold av etikkarbeid i positiv eller negativ retning.

To av forskerne utførte den videre analysen, en deskriptiv innholdsanalyse (Patton 2002), der svarene ble kategorisert og kondensert (Braun \& Clarke 2006). I analyseprosessen beveget vi oss fram og tilbake mellom grunnlagsmaterialet og de temaene vi samlet oss om, for å sjekke at det var samsvar. Analysen ble diskutert med alle medforfatterne. Vi har valgt ut illustrerende sitater som representerer typiske erfaringer og synspunkter. Der materialet ga grunnlag for det, har vi gjort en enkel opptelling, for eksempel av andel respondenter som svarte at kommunen fortsatt var i gang med etikkarbeid.

\section{Forskningsetikk}

Studien krevde ingen godkjenning fra De regionale komiteer for medisinsk og helsefaglig forskningsetikk (REK), men ble meldt til Norsk samfunnsvitenskapelig datatjeneste (NSD). Vi fulgte allmenne forskningsetiske prinsipper for informert samtykke, frivillighet og konfidensialitet. Forskerne som gjennomførte studien, er lønnet fra $\mathrm{UiO}$ gjennom forskningsmidler fra Helse- og omsorgsdepartementet.

\section{Resultater}

De fleste kontaktpersonene kjente godt til etikkprosjektet i sin kommune, og noen hadde deltatt aktivt i prosjektet. Seks kontaktpersoner hadde imidlertid liten kunnskap om hvordan tiltakene var utformet lokalt, for eksempel om hvor mange som deltok ved ulike tjenestesteder. Manglende kunnskap var dels forårsaket av at kontaktpersonene ikke hadde deltatt i prosjektet fra starten av, dels at de ikke hadde tett nok kontakt med tjenestestedene.

Det var stor variasjon mellom kommunene med hensyn både til type tiltak, organisering og ressursbruk. I det videre beskriver vi først hvilke tiltak som var iverksatt hvor, hvordan disse var organisert, og om de hadde fortsatt utover prosjektperioden. Videre 
beskriver vi ressursinnsats, herunder kompetansehevende tiltak og metoder for etikkrefleksjon, og til slutt ser vi på hvordan prosjektet var forankret lokalt.

\section{Hvilke tiltak var iverksatt, og hvordan var de organisert?}

Tabell 1 gir en oversikt over antallet kommuner som hadde etablert ulike former for etikktiltak. Med tiltak mener vi her møteplasser for etikkrefleksjon. Resultatene viser at etikkrefleksjon i hovedsak enten skjedde på egne arenaer, som i refleksjonsgrupper og etikk-komiteer eller var lagt inn som en del av et annet møte, for eksempel personalmøtet.

Vi har her skilt mellom såkalte ressurskommuner og de øvrige kommunene.

Tabell 1: Oversikt over ulike etikktiltak i kommunene

\begin{tabular}{|l|c|c|c|c|c|}
\hline Kommuner & $\begin{array}{c}\text { Egne arenaer } \\
\text { eller møter for } \\
\text { etikkrefleksjon }\end{array}$ & $\begin{array}{c}\text { Etikkreflek- } \\
\text { sjon som en del } \\
\text { av et annet } \\
\text { møte }\end{array}$ & $\begin{array}{c}\text { Annet } \\
\text { Ingen } \\
\text { tiltak }\end{array}$ & Sum \\
\hline Ressurskommuner & 8 & & & & 8 \\
\hline Pulje 1-kommuner & 14 & 5 & 3 & 5 & 27 \\
\hline
\end{tabular}

Fem kommuner hadde ikke kommet i gang med noen form for etikkarbeid. Et par av disse hadde gjort spredte forsøk, men kom aldri ordentlig i gang. Det er vanskelig å finne en felles begrunnelse for eller årsak til dette, men kontaktpersonene peker på forhold som kan ha aktualitet for flere:

Vi er så få og skal følge med på så mye, og vi klarer ikke å følge med på alt - der ligger noe av forklaringen. ... Vi har så kolossalt mange elementer vi må ta fatt $i$ og etikken var et av dem som vi kan si at vi kan legge til side, for det er ikke fullt så farlig.

Det er verken behovet eller tiden det skorter på, men mer organiseringen.

\section{Type tiltak}

22 av 34 kommuner hadde etablert egne møteplasser for refleksjon der det var satt av tid og rom til å reflektere over etiske utfordringer i en gruppe. Det gjaldt samtlige ressurskommuner, som hadde etablert to hovedformer for tiltak: refleksjonsgrupper og klinisk etikk-komité / etisk råd. Tre av åtte ressurskommuner driftet fortsatt begge typer tiltak, mens én utelukkende hadde satset på klinisk etikk-komité for sykehjemmene.

Av de 27 Pulje 1-kommunene praktiserte 14 etikkrefleksjon i egne grupper, mens fem hadde lagt etikkrefleksjonen til eksisterende møter, for eksempel personal- eller avdelingsmøter. Av andre tiltak kan nevnes det kontaktpersonene betegnet som «etisk kafé», arrangert et par-tre ganger i halvåret, der etiske utfordringer ble drøftet. Etisk kafé er en 
møteplass for brukere, pårørende, ansatte og politikere, der en på en uformell måte kan samtale om et aktuelt etisk tema knyttet til tjenesten (Eide \& Aadland 2011).

\section{Hvordan har etikkprosjektet vært organisert?}

Med organisering menes i denne sammenheng hvilke tjenestesteder som har vært omfattet av etikksatsingen, og hvor mye tid enhetene har brukt på etikkarbeidet.

\section{Hvilke tjenestesteder har deltatt i prosjektet?}

I de fleste kommunene var tilbudene etablert i både sykehjem og hjemmetjenester, flest i sykehjem. I underkant av halvparten av kommunene hadde også inkludert boliger for psykisk utviklingshemmede og noen også helsetjenester for psykiatri og rus samt helsesentre. Det var stor variasjon mellom kommunene i hvor mange avdelinger som hadde deltatt innen hver enhet, og det hadde også variert noe over tid.

I hovedsak ble refleksjonsgruppene drevet på avdelingsnivå, men noen få steder, både i sykehjem og hjemmetjenesten, foregikk etikkrefleksjon på tvers av avdelinger.

Med få unntak hadde de fleste kommunene etablert det de betegnet som «åpne» grupper, det vil si at alle som var på jobb den dagen, kunne delta. Gruppene var i hovedsak tverrfaglige, med vekt på ansatte som sto i pasientrettet arbeid. Leger deltok med få unntak bare i kliniske etikk-komiteer. Deltakelse i refleksjonsgruppene var ikke obligatorisk, med mindre etikkrefleksjon var lagt inn som 10-15 minutters bolk i et obligatorisk avdelingsmøte.

Mange informanter hadde ikke detaljkunnskap om oppslutningen, for eksempel hvor stor andel av de ansatte som deltok.

\section{Tidsbruk}

Det var stor variasjon i hvor ofte tjenestestedene arrangerte etikkrefleksjon (fra hver uke til én gang per måned), og i hvor mye tid som ble satt av (fra 15 til 90 minutter) hver gang. Noen tjenestesteder brukte for eksempel halvannen time en gang per måned, noen en time annenhver uke, mens andre hadde et møte på 20-25 minutter en gang i uka. Noen informanter var usikre på tidsbruken. Det ble satt av mest tid der etikkrefleksjon var definert som et selvstendig forum, sammenliknet med der etikkrefleksjonen var lagt inn som et punkt i personalmøtet. Her fikk etikkrefleksjon oftest bare 10-15 minutter. Ressurskommunene brukte gjennomgående noe mer tid enn de andre kommunene.

\section{Jobber kommunene fortsatt med etikk?}

Et av kriteriene for tildeling av den årlige «Etikkprisen» som KS deler ut, er om etikkarbeidet i kommunen er systematisk og varig (KS 2014b). Evalueringen viste at de aller fleste kommunene fortsatt jobbet med etikk, det vil si at de hadde klart å videreføre etikksatsingen i en eller annen form. I tillegg til de fem kommunene som aldri kom i gang med 
systematisk etikkarbeid, var det imidlertid også fem kommuner som ikke hadde klart å videreføre arbeidet med etikk utover den første prosjektperioden på et halvt til ett år:

To av kommunene der virksomheten lå nede, hadde imidlertid planer om å starte opp igjen.

Et par kommuner hadde endret møteplass, det vil si flyttet etikk-refleksjonen fra egne refleksjonsgrupper til et punkt på personalmøtet. Det betød samtidig mindre tid til å drøfte etiske utfordringer i arbeidet.

Samtlige ressurskommuner jobbet fortsatt systematisk med etikk i flere typer enheter, selv om omfang og intensitet hadde variert noe over tid.

\section{Ressurser til etikkarbeidet}

Med ressurser menes både økonomiske midler og tid til å utvikle ansattes etikk-kompetanse. Resultatene viser store variasjoner i ressurser gitt til etikksatsingen. Mens vel en tredel sa at det ikke var satt av noen ressurser til etikksatsingen, hadde man i andre kommuner fått frikjøpt tid for en prosjektleder i 10 til 60 prosent stilling. I mange kommuner var prosjektlederfunksjonen også koblet til andre fagutviklingsprosjekter. Variasjoner til tross er vår generelle oppfatning at det har vært formidlet fra kommunene at etikksatsingen ikke skulle kreve ekstra ressurser.

Vi har ikke hatt noen ressurser til satsningen. Det har hele tiden voert et mål at dette skal vore en del av den ordinoere driften.

Likevel fortalte informantene at det var gjennomført mange ressurskrevende tiltak, hovedsakelig opplæring av ansatte. Det tiltaket som framfor noe var prioritert, var «Nordpå-kurset», som fra KS’ side var presentert som et sentralt opplæringstilbud. Mens tre informanter sa at kommunen ikke hadde deltatt fordi kurset var for dyrt, hadde de resterende deltatt med to til femti deltakere. Svarene tilsier at ca. 300 personer fra de 34 kommunene hadde deltatt i Nordpå-kurset. Mens flere ga uttrykk for at dette var et positivt bidrag, uttrykte andre betydelig skepsis til kursets innhold og læringsutbytte, for eksempel at det man hadde lært, i liten grad ble brukt i kompetansespredning etter kurset.

De fleste kommunene hadde deltatt på KS’ oppstartkonferanse. For mange fungerte dette etter intensjonen, nærmest som et «kick-off». Andre kom hjem og strevde med å komme i gang. Både de fem kommunene som aldri kom i gang, og de kommunene der etikkarbeidet hadde stoppet opp, hadde deltatt på både oppstartkonferansen og Nordpåkurset.

Utover dette hadde et flertall av kommunene på eget initiativ iverksatt en rekke kompetanseutviklende tiltak, rettet mot både ansatte og ledere. Varigheten av disse varierte fra et par timers kurs til en rekke kursdager.

Alle kommunene hadde oppnevnt en eller flere personer til å lede den lokale etikkrefleksjonen, såkalte ressurspersoner eller etikkveiledere, som hadde fått KS’ opplæringstilbud. Noen av disse var også prosjektledere. Men bare rundt en tredjedel av kommunene 
hadde én eller flere ressurspersoner med formell kompetanse i etikk, en kompetanse de eksempelvis hadde ervervet gjennom ulik studiepoenggivende utdanning i etikk ved høgskoler. De kommunene som enten ikke hadde kommet ordentlig i gang, eller der det hadde stoppet opp, hadde ikke hatt personer med formell kompetanse. Et gjennomgående funn er etterlysningen av etikk-kompetanse, en kompetanse som ikke utvikles gjennom deltakelse på et dagskurs. Flere informanter etterlyste tilbud om «etterveiledning» for dem som leder refleksjonen på tjenestestedene.

\section{Metoder og verktoy for refleksjonsarbeid}

Med unntak av i de fem kommunene som aldri kom i gang, beskrev alle kontaktpersonene startperioden som en tid med utprøving av flere metoder, både for å stimulere deltakerne til dialog og for å strukturere refleksjonen. Etikkhåndbokas forslag til metoder og tiltak hadde vært utgangspunkt for mange, men vårt inntrykk er at det først og fremst er de enkle metodene som har vært prøvd, for eksempel refleksjonskort. Her var det blandede erfaringer:

Vi har prøvd oss på forskjellige ..., og så har vi brukt kortene. Men vi har kommet fram til at det er litt vanskelig å bruke sånne kunstige problemstillinger. ... Så det vi har funnet ut, er at det å utfordre ansatte til å legge fram problemstillinger de ønsker å reflektere over, ... og det er problemstillinger alle står i. Det er det som funker best. Så har vi litt fri refleksjon rundt det.

Vel halvparten hadde forsøkt «fishbowl»-metoden, en sentral metode i Nordpå-kurset. Imidlertid svarte bare tre at denne modellen fortsatt brukes. Flere ga uttrykk for at de opplevde at metoden førte til en kunstig samtale, og at den ikke svarte til forventningene. Noen opplevde at vektleggingen av denne metoden hadde forstyrret læring av andre, kanskje mer hensiktsmessige metoder:

Vi har loert «fishbowl»-metoden, men vi bruker den lite. Folk syns den er komisk, rigid, og den oppleves hemmende mer enn fremmende på refleksjonen ... Fiskebollemetoden har forstyrret åpenheten for andre metoder.

«Etisk refleksjonsmodell», slik den blant annet beskrives i Etikkhåndboka (Eide \& Aadland 2011), anvendes i mindre grad, og først og fremst av ressurskommunene.

«Fri refleksjon», det vil si samtaler om etiske utfordringer uten noen bestemt metode for å systematisere og strukturere refleksjonen, synes å være ganske vanlig. I underkant av halvparten svarte at dette nå var mest vanlig, og samtalene kunne dreie seg om caser, om tema eller verdiord. Fravær av systematikk i etikkrefleksjonen synes også å ha preget de kommunene som ikke har klart å videreføre etikksatsingen.

Mange informanter ga uttrykk for usikkerhet og manglende kompetanse i metoder for å stimulere og strukturere etikkrefleksjonen ute på tjenestestedene. Flere sa eksplisitt at opplæring og øvelse i metoder var et savn blant dem som drev etikkarbeidet. 


\section{Hva blir droftet i etikkrefleksjonen?}

Vel halvparten fortalte at det oftest var situasjoner fra ansattes egen praksis i sykehjem eller hjemmetjeneste som var utgangspunkt for drøftingene. Noen (ca. en firedel) tok utelukkende utgangspunkt i verdier, sentrale begreper eller mer generelle temaer, mens andre fortalte at det varierte, det vil si at noen ganger var generelle temaer utgangspunkt for refleksjonen, andre ganger var det konkrete caser. Informantene hadde liten kunnskap om det konkrete innholdet i de situasjonene som ble drøftet.

Kort oppsummert viste resultatene at vel halvparten av de kommunene som fortsatt gjennomførte etikkrefleksjon, gjorde det med utgangspunkt i egen praksis, men først og fremst som «fri refleksjon», uten hjelp av metoder som systematiserer refleksjonen.

\section{Forankring}

Med forankring mener vi i denne sammenheng om etikksatsingen lokalt har fått støtte på politisk og administrativt nivå, og om ledelsen på virksomhets- og mellomledernivå støtter og legger til rette for systematisk etikkrefleksjon.

Litt under halvparten av informantene svarte at prosjektet har vært forankret hos øverste ledelse i kommunen. Men den praktiske betydningen av dette varierte:

På papiret er forankringen god. Kommunaldirektøren er styringsgruppe ... Direktøren burde vart tydeligere overfor lederne med hensyn til deres ansvar for å påvirke ute på tjenestestedene.

Dette sitatet indikerer behov for en mer helhetlig forankring i flere ledd i organisasjonen, med ønske om kontakt mellom ledelsesnivåene også etter oppstart av prosjektet.

Ledelsesforankring handler om forankring både på virksomhetsnivå og på mellomledernivået ute i virksomhetene, det vil si hos avdelingsledere på sykehjem og hjemmetjeneste. Vel halvparten av de spurte sa at etikksatsingen var forankret hos virksomhetsledelsen for de aktuelle tjenestene. Samtidig viste intervjuene en svakere forankring på avdelingsnivå. Dette illustreres ved følgende sitat fra en kommune som satset, men etter et halvår dabbet det hele av:

Etikksatsingen var forankret på toppen. Helse- og omsorgssjefen sa at dette skulle vi. Også politisk nivå var informert og stilte seg positive. Rådmannen var også positiv... etterlyste det og ville at det skulle fortsette å gjelde for hele kommunen. Etikksatsingen var ikke godt nok forankret $i$ virksomhetene soerlig utfordrende var dette med mellomledernes rolle. Satsingen var ikke tilstrekkelig forankret hos mellomlederne ...

Slike erfaringer var ganske vanlige både blant dem som ikke hadde klart å videreføre etikkprosjektet og dem som aldri kom ordentlig i gang med etikksatsingen.

Alt i alt ser vi at ressurskommunene har forankret sine etikkprosjekt noe bedre enn de øvrige kommunene, både på politisk, virksomhets- og avdelingsledernivå. Noen få har også sørget for forankring hos de ansatte, enten ved behovsundersøkelser, gjennom at tillitsvalgte er representert i prosjektledelsen, eller på annen måte. 
Med unntak av i to kommuner var det ikke gjennomført skriftlige evalueringer. En kommune hadde gjennomført en muntlig evaluering, og noen hadde laget årsrapporter der tiltakene var beskrevet, men ikke evaluert.

\section{Diskusjon}

«Samarbeid om etisk kompetanseheving i kommunene» er et bredt anlagt, ambisiøst og ressurskrevende prosjekt. Hensikten er å heve etikk-kompetansen og stimulere til etikkrefleksjon i praksis for derved å bedre kvaliteten på tjenesten og styrke de ansatte i arbeidet. Så vidt vi kjenner til, finnes ikke tilsvarende satsinger på etikk $i$ andre europeiske eller nordamerikanske land.

Kort oppsummert viser resultatene:

- Satsingen på etikk har i de fleste kommuner hatt ganske stor utbredelse. Det vil si at møteplasser for etikkrefleksjon ble etablert ved flere tjenestesteder i flertallet av kommunene.

- De fleste benyttet seg av KS’ tilbud om etikkopplæring, hvorav noen tilbud synes å ha fungert etter intensjonen, mens det kan stilles spørsmål ved nytten av andre tilbud.

- Resultatene viser behov for ytterligere kompetanse i etikk og metode blant dem som leder etikkarbeidet, og det synes vanskelig å få til mer systematisk etikkrefleksjon.

- Det var stor variasjon i hvordan etikkarbeidet er forankret i kommunen,

- Noen kommuner kom ikke i gang med etikkarbeidet, og noen hadde ikke videreført satsingen.

Skal målsettingen om etisk kompetanseheving nås, ansees det som viktig at etikkarbeidet er systematisk og varig (KS 2014b). Vi vil i det videre derfor drøfte to forhold som synes å ha betydning for dette: kompetanse til å lede etikkrefleksjon, herunder valg av metoder for refleksjon, og forankring av prosjektet $i$ kommunen.

\section{Kompetanse og metoder for refleksjon}

Behovet for kompetanse til å lede og strukturere den etiske refleksjonsprosessen er et av studiens sentrale funn. Dette er resultater som sammenfaller med annen praksisforskning - å stimulere til refleksjon krever spesifikk kompetanse (Gjerberg \& Amble 2011b; Lillemoen \& Kristoffersen 2010), men også oppfølging over tid. Deltakelse på oppstartkonferansen og Nordpå-kurs var ment som en «startpakke» i ressurspersonenes kompetanseutvikling - som læring av enkle metoder som skulle stimulere kommunene til å etablere etikkrefleksjon. Og etter vår vurdering lyktes man i hovedsak med dette, det vil si at tilbudene for de fleste fungerte som inspirasjon til å starte opp. Samtidig indikerer resultatene at dersom etikkrefleksjon skal være systematisk og vare ved, trenger de som skal lede satsningen, både grunnleggende kompetanse og oppfølging over tid for å bli trygge i å lede etikkrefleksjon på egen arbeidsplass. 
Respondentene beskriver tiden etter de to kursene som en tid preget av utprøving av flere av de enkle metodene. Til tross for iherdige forsøk synes utrygghet i metodebruk sammen med en gradvis økende skepsis til noen av metodenes egnethet for etisk refleksjon å ha preget tiden.

De kompetanseutviklingstiltakene kommunene selv hadde igangsatt, var i stor grad konsentrert om etikkdager med eksterne forelesere, mindre om samlinger hvor ressurspersonene selv kunne diskutere etikkrefleksjon, utveksle erfaringer med tilrettelegging av slike prosesser og ikke minst trene på å lede etikkrefleksjon, det vil si veiledning og oppfølging over tid for å bygge og trygge kompetanse.

Behovet for mer kompetanse og oppfølging kan trolig bidra til å forklare hvorfor såkalt fri refleksjon var så utbredt. Læring og fagutvikling er en pågående prosess (Molander 1990), som krever mer enn tilførsel av kunnskap over noen få kursdager. Selv om en sentral målsetting for prosjektet var systematisk etikkrefleksjon, er det mer mangelen på systematikk som kjennetegner etikkrefleksjonen i mange kommuner. Kanskje ville det også gitt større læringsutbytte dersom man hadde satset på én eller få metoder, slik at ressurspersonene kunne bli trygge på en metode når de skulle lede refleksjonsgruppene.

Valg av metode kan kanskje også sees i sammenheng med tjenestestedenes villighet til å bruke tid på etikkarbeidet; for eksempel krever diskursetiske metoder mer tid enn 1520 minutter.

Trolig ville en sterkere satsing på opplæring av ressurspersonene, med oppfølging og øvelser, ført til at flere hadde lyktes. Når det er sagt, er det viktig å trekke fram at noen har lyktes, mange fordi de har hatt, eller også selv tatt, ansvaret for å utdanne ressurspersoner som skal ta ansvaret for å lede etikkrefleksjonen.

\section{Forankring}

Resultatene indikerer at det er nødvendig å forankre etikksatsingen på flere nivåer i kommunen. Det synes ikke tilstrekkelig at politisk og administrativ ledelse nedfeller satsing på etikk i visjoner, mål og kjerneverdier for kommunen eller i politiske vedtak. Dette gir et godt utgangspunkt, men det virker helt nødvendig å konkretisere satsingen ved å engasjere og forplikte ledelsen på flere nivåer, som virksomhets- og avdelingsnivå. Forankring på virksomhetsnivå er viktig og nødvendig, men heller ikke dette synes tilstrekkelig. Denne forankringen er nødvendig fordi virksomhetslederne må gi signaler til avdelingslederne om prioriteringer av oppgaver og derved nødvendig legitimitet til etikkarbeidet i avdelingene. Men lokale ildsjeler som har startet etikkarbeid på sine tjenestesteder, synes også å trenge mer konkret oppfølging fra sin nærmeste leder. Uten en slik støtte ser det ut til å være en fare for at etikksatsingen blir kortvarig. Slik tidligere studier indikerer, er positive holdninger ikke tilstrekkelig for å få til kunnskapsoverføring og endring (Snibsøer et al. 2012). Det holder ikke at avdelingslederen godtar at noen starter refleksjonsgrupper på avdelingen. Hun/han må også legge forholdene til rette for at refleksjonen kan gjennomføres i praksis, for eksempel gjennom å ta ansvar for å organisere avdelingens arbeidsoppgaver slik at flest mulig ansatte kan delta i avdelingens avtalte etikkre- 
fleksjon, samt å «skjerme» nok tid til refleksjon. Også andre studier viser nødvendighet av sosial støtte i miljøet for at etikkrefleksjon kan gjennomføres (Soderhamn et al. 2014).

Der etikkrefleksjonen bare legges inn som en kort sekvens i etablerte møter, indikerer resultatene at den lett skyves til side for «viktigere» saker, og det kan stilles spørsmål ved prioriteringen av etikkarbeidet. Systematisk etikkrefleksjon krever mer tid enn ti-femten minutter, både for å belyse ulike synspunkter og for å stimulere til medvirkning i diskusjonen.

Fra tidligere studier vet vi at ressurspersonene som leder denne type arbeid, trenger støtte og oppmuntring, både i den praktiske organiseringen og gjennom at tiltaket etterspørres (Gjerberg \& Amble 2011a). Hvis ressurspersonene opplever å stå alene med ansvaret, kan de lett gå tomme og brenne ut. Utfordringer knyttet til ledelsesforankring er imidlertid ikke uvanlig når ny kunnskap skal omsettes til praksis (Malmberg-Heimonen \& Tøge 2014).

Etikkarbeidet synes sjelden å være forankret på «grunnplanet»; bare unntaksvis hadde man undersøkt hvilke behov og ønsker de ansatte hadde. Dette er viktig for å målrette tiltakene, å forplikte de ansatte til å delta samt å få viktige innspill til evaluering. Våre funn synes således å være i tråd med annen forskning og teori på området (Kitson 2009; McCormack et al. 2002; Sandvik et al. 2011); ansatte må involveres i prosessen, og prosjektet må forankres på flere ledelsesnivåer for å få den ønskede virkning av tiltaket.

\section{Svakheter ved studien}

Evaluering av denne type virksomhet er viktig, både av hensyn til effektiv ressursbruk og fordi prosjektet fortsatt er under utvikling (Craig et al. 2008; Pedersen et al. 2010).

Denne evalueringen har imidlertid noen svakheter. Den største svakheten er at noen kontaktpersoner ikke var tilstrekkelig oppdatert til å kunne gi detaljerte opplysninger om hvordan det ble jobbet ute på de lokale tjenestestedene, fordi de ikke var tett nok på virksomheten ute på tjenestestedene. Derimot hadde de aller fleste god oversikt over opplæring, forankring og hva slags type tiltak som var iverksatt hvor. Våre informanter var henholdsvis personer som KS anbefalte som best informert om etikkprosjektet i de respektive inkluderte kommunene, som kommunene selv mente hadde best informasjon om prosjektet, eller som vi «nøstet» oss fram til i de tilfellene der kontaktpersonen hadde sluttet. Intervju med de som har ledet og/eller har deltatt i etikkrefleksjon, ville gitt et viktig supplement og større tyngde til materialet, men ville på daværende tidspunkt ha sprengt rammene for prosjektet; vi ville da bare ha kunnet inkludere et fătall kommuner. En slik datainnsamling er nå gjennomført i noen av kommunene, og resultatene vil foreligge i en egen artikkel.

Å intervjue på telefon er kostnadsbesparende i forhold til å gjøre personlig intervju i ulike deler av landet, men metoden har samtidig noen svakheter (Novick 2008; Sturges \& Hanrahan 2004). Når en ikke kan observere nonverbal kommunikasjon og kontekstuelle forhold, kan noe av samtalepreget i intervjuet reduseres (Tjora 2012). Det blir desto viktigere å forsikre seg om at en har forstått hva informanten svarer, for eksempel ved å gjenta deler av svaret og spørre om det var dette de mente. Studier som har sammenliknet 
ulike former for kvalitative intervjuer, gir imidlertid lite dokumentasjon på at data innhentet via telefonintervju er av dårligere kvalitet enn intervjuer ansikt til ansikt (Novick 2008).

Det finnes lite evaluering av systematisk etikkarbeid i kommunehelsetjenesten. På tross av dens begrensninger mener vi studien gir viktige innspill om hvordan etikkarbeidet $\mathrm{i}$ kommunenes helse- og omsorgstjeneste bør innrettes fremover.

\section{Konklusjon}

For å møte framtidens krav til en god eldreomsorg må arbeidsplassene utvikles som læringsarenaer der ansattes etikk-kompetanse er et viktig element. Spørsmålet er hvordan man best kan utvikle og trene etisk refleksjon i denne type handlingsintensivt arbeid, slik at organisasjonene bygger kompetanse i et langsiktig perspektiv. Denne studien illustrerer at kunnskapsoverføring er komplisert og byr på utfordringer på flere nivåer. Forankring hos ledelse og ansatte, gode metoder, og kunnskapsoppbygging og oppfølging over tid for dem som leder etikkrefleksjonen, synes å være viktige forutsetninger for å etablere og vedlikeholde etikkrefleksjon som en naturlig del av praksis. Her synes ressurskommunene å være i en særstilling. Selv om utvikling av systematisk etikkarbeid er krevende, er det mange grunner til å anta at etikksatsingen i mange av landets kommuner har hatt og vil ha stor betydning fremover, ikke minst fordi tiltakene justeres ut fra de erfaringer som gjøres. En nødvendig forutsetning er imidlertid at en også lokalt evaluerer tiltak som iverksettes.

\section{Noter}

${ }^{1}$ Deltakerne sitter i ring og får ordet på omgang. Det er en styrt samtale, der en person starter med en uttalelse om en etisk utfordring eller problem, som så benyttes som grunnlag for neste persons uttrykte tanke: «Når du sier det ..., tenker jeg ...», samtidig som hun/han vender seg mot en tredje person, som så følger opp. Øvelsen betegnes som en kommunikasjonsmetode som både er en lytteøvelse og en teknikk for hypotesedannelse (Soderhamn et al. 2014).

${ }^{2}$ Intervjuguiden kan fås ved henvendelse til korresponderende forfatter.

\section{Litteratur}

Bollig, G., Pedersen, R. \& Forde, R. (2009) Etikk i sykehjem og hjemmetjenester. Sykepleien Forskning, 4 (3), s. 186-196.

Børslett, E. J. A., Heilmann, G., Lillemoen, L. \& Pedersen, R. (2011) La etikken blomstre i praksis en bok om systematisk refleksjon $i$ arbeidshverdagen. Oslo: Senter for medisinsk etikk, UiO.

Braun, V. \& Clarke, V. (2006) Using thematic analysis in psychology. Qualitative Research in Psychology, 3 (2), s. 77-101. 
Brown, B. A., Miles, S. H. \& Aroskar, M. A. (1987) The prevalence and design of ethics committees in nursing homes. Journal of the American Geriatrics Society, 35 (11), s. 1028-1033.

Craig, P., Dieppe, P., Macintyre, S., Michie, S., Nazareth, I. \& Petticrew, M. (2008) Developing and evaluating complex interventions: the new Medical Research Council guidance. British Medical Journal, 337, a1655, available from: PM:18 824488

Det kongelige helse- og omsorgsdepartement (2006) St.meld. nr 25 (2005-2006), Mestring, muligheter og mening. Oslo

Eccles, M., Grimshaw, J., Walker, A., Johnston, M. \& Pitts, N. (2005) Changing the behavior of healthcare professionals: the use of theory in promoting the uptake of research findings. Journal of Clinical Epidemiology, 58 (2), s. 107-112, available from: PM:15 680740

Eide, T. \& Aadland, E. (2008) Etikkhåndboka for kommunenes helse-og omsorgstjenester. Oslo: Kommuneforlaget AS.

Eide, T. \& Aadland, E. (2011) Etikkhåndboka. Oslo: Kommuneforlaget.

Forde, R. \& Aasland, O.G. (2013) Moral distress and professional freedom of speech among doctors. Tidsskrift for Den Norske Legeforening, 133 (12-13), s. 1310-1314, available from: PM:23 817260

Forde, R. \& Vandvik, I.H. (2005) Clinical ethics, information, and communication: review of 31 cases from a clinical ethics committee. Journal of Medical Ethics, 31 (2), s. 73-77, available from: PM:15 681669

Forsetlund, L., Bjorndal, A., Rashidian, A., Jamtvedt, G., O'Brien, M.A., Wolf, F., Davis, D., Odgaard-Jensen, J. \& Oxman, A.D. (2009) Continuing education meetings and workshops: effects on professional practice and health care outcomes. Cochrane Database. Systematic Reviews (2) CD003 030, available from: PM:19 370580

Foxcroft, D.R. \& Cole, N. (2003) Organisational infrastructures to promote evidence based nursing practice. Cochrane Database. Systematic Reviews. (4), CD002 212 available from: PM:14 583946

Gale, B.V. \& Schaffer, M.A. (2009) Organizational readiness for evidence-based practice. Journal of Nursing Administration, 39 (2), s. 91-97, available from: PM:19 190426

Gjerberg, E. \& Amble, N. (2011a) Refleksjon, handling og mestring. Et forsknings- og utviklingsprosjekt, 2005-2011. Arbeidsforskningsinstituttet, Oslo.

Gjerberg, E. \& Amble, N. (2011b) Train the trainer - refleksjonsgrupper i pleie- og omsorgstjenesten. Sykepleien Forskning, (2), s. 134-141.

Gjerberg, E., Forde, R., Pedersen, R. \& Bollig, G. (2010) Ethical challenges in the provision of end of life care in Norwegian nursing homes. Social Science \& Medicine, 71, s. 677-684.

Glasser, G., Zweibel, N.R. \& Cassel, C.K. (1988) The ethics committee in the nursing home. Results of a national survey. Journal of the American Geriatrics Society, 36 (2), s. 150-156.

Kalager, G., Forde, R. \& Pedersen, R. (2011) Is the discussion of patient cases in clinical ethicscommittees useful? Tidsskrift for Den Norske Legeforening, 131 (2), s. 118-121, available from: PM:21 267026

Kalvemark, S., Hoglund, A.T., Hansson, M.G., Westerholm, P. \& Arnetz, B. (2004) Living with conflicts-ethical dilemmas and moral distress in the health care system. Social Science and Medicine, 58 (6), s. 1075-1084, available from: PM:14 723903

Kitson, A.L. (2009) The need for systems change: reflections on knowledge translation and organizational change. Journal of Advanced Nursing, 65 (1), s. 217-228, available from: PM:19 032518

KS (2014). Etikkprisen. Lastet ned fra http://www.ks.no/tema/Helse-og-velferd/Samarbeid-foretisk-kompetanseheving/Gode-eksempler/Etikkprisen-2014--Okonomisk-stotte-heder-ogare-i-premie1/ 
Kvale, S., Brinkmann, S., Rygge, J. \& Anderssen, T.M. (2009) Det kvalitative forskningsintervju (2. utg.) Oslo: Gyldendal Akademisk.

Lillemoen, L. \& Kristoffersen, N.J. (2010) Veiledningsgruppe for studentansvarlige sykepleiere i klinisk praksis. Utvikling av veiledningskompetanse. Norsk tidsskrift for sykepleieforskning, 12 (2), s. 3-14.

Lillemoen, L. \& Pedersen, R. (2013) Ethical challenges and how to develop ethics support in primary health care. Nursing Ethics, 20 (1), s. 96-108, available from: PM:22 918061

Malmberg-Heimonen, I. N. S. \& Tøge, A. G. (2014) Evaluering av "helhetlig, prinsippstyrt, metodisk tilnærming" (HPMT). En klynge-randomisert studie. Arbeid og velferd, (2), s. 60-72.

McCarthy, J. \& Deady, R. (2008) Moral distress reconsidered. Nursing Ethics, 15 (2), s. 254-262, available from: PM:18 272615

McCormack, B., Kitson, A., Harvey, G., Rycroft-Malone, J., Titchen, A. \& Seers, K. (2002) Getting evidence into practice: the meaning of 'context'. Journal of Advanced Nursing, 38 (1), s. 94-104, available from: PM:11 895535

Molander, B. (1990) Kunnskapers tysta och tystade sidor - et försök til översikt. Nordisk Pedagogik, 3, s. 99-113.

Molewijk, B., Verkerk, M., Milius, H. \& Widdershoven, G. (2008). Implementing moral case deliberation in a psychiatric hospital: process and outcome. Medicine, Health Care and Philosophy, 11 (1), s. 43-56, available from: PM:18 165908

Novick, G. (2008) Is there a bias against telephone interviews in qualitative research? Research in Nursing and Health, 31 (4), s. 391-398, available from: PM:18 203128

Osborne, T., Lacy, N. L., Potter, J. F. \& Crabtree, B. F. (2000) The prevalence, composition, and function of ethics committees in nursing facilities: results of a random, national survey of American Health Care Association members. Journal of the American Medical Directors Association, 1 (2), s. 51-57, available from: PM:12 818031

Patton, M. Q. (2002) Qualitative Research \& Evaluation Methods (3 ed.). Thousand Oaks: Sage Publications.

Pedersen, R., Hofmann, B. \& Mangset, M. (2007) Pasientautonomi og informert samtykke i klinisk praksis [Patient autonomy and informed consent in clinical practice]. Tidsskrift for Den Norske Legeforening, 127 (12), s. 1644-1647, available from: PM:17 571103

Pedersen, R., Hurst, S. A., Schildmann, J., Schuster, S. \& Molewijk, A. C. (2010) The development of a descriptive evaluation tool for clinical ethics case consultation. Clinical Ethics, 5 (3), s. 136141.

Sandvik, G. K., Stokke, K. \& Nortvedt, M. W. (2011) Hvilke strategier er effektive ved implementering av kunnskapsbasert praksis i sykehus? Sykepleien Forskning, 6 (2), s. 160-167.

Schick, I. C. \& Moore, S. (1998) Ethics committees identify four key factors for success. HEC Forum, 10 (1), s. 75-85, available from: PM:10 178385

Schneiderman, L. J., Gilmer, T., Teetzel, H. D., Dugan, D. O., Blustein, J., Cranford, R., Briggs, K. B., Komatsu, G. I., Goodman-Crews, P., Cohn, F. \& Young, E. W. (2003) Effect of ethics consultations on nonbeneficial life-sustaining treatments in the intensive care setting: a randomized controlled trial. JAMA, 290 (9), s. 1166-1172, available from: PM:12 952998

Schön, D. (1987) Educating the Reflective Practitioner. San Fransisco, Jossey-Bass Publishers.

Senge, P. M. (1990) The fifth discipline: The art and practice of the learning organization. New York, Doubleday.

Senter for medisinsk etikk, UiO (2011) Nasjonalt mandat for kliniske etikk-komiteer.

Slettebo, A. \& Bunch, E. H. (2004) Solving ethically difficult care situations in nursing homes. Nursing Ethics, 11 (6), s. 543-552, available from: PM:15 597935

Snibsøer, A. K., Olsen, N. R., Espehaug, B. \& Nortvedt, M. W. (2012) Holdning og atferd knyttet til kunnskapsbasert praksis. Sykepleien Forskning, 7 (3), s. 234-241. 
Soderhamn, U., Kjostvedt, H. T. \& Slettebo, A. (2014) Evaluation of ethical reflections in community healthcare: A mixed-methods study. Nursing Ethics, available from: PM:24 714049

Solum, E.M., Slettebo, A. \& Hauge, S. (2008) Prevention of unethical actions in nursing homes. Nursing Ethics, 15 (4), s. 536-548, available from: PM:18 515442

Statens Helsetilsyn (2010) Tilsynsmelding 2010. Lastet ned fra http://www.helsetilsynet.no/upload/ Publikasjoner/tilsynsmelding/tilsynsmelding2010.pdf

Sturges, J. K. \& Hanrahan K. J. (2004) Comparing Telephone and Face-to-face Qualitative Interviewing: a Research Note. Qualitative Research, 4 (1), s. 107-118.

Thompson, M. A. \& Thompson, J. M. (1990) Ethics committees in nursing homes: a qualitative research study. HEC Forum, 2 (5), s. 315-327, available from: PM:10 106995

Tjora, A. (2012) Kvalitative forskningsmetoder i praksis (2 ed.) Oslo: Gyldendal Akademisk.

van der Dam, S., Abma, T. A., Molewijk, A. C., Kardol, M.J., Schols, J.M., \& Widdershoven, G.A. (2011) Organizing moral case deliberation experiences in two Dutch nursing homes. Nursing Ethics, 18 (3), s. 327-340, available from: PM:21 558109

Weston, C. M., O'Brien, L. A., Goldfarb, N. I., Roumm, A. R., Isele, W. P. \& Hirschfeld, K. (2005) The NJ SEED project: evaluation of an innovative initiative for ethics training in nursing homes. Journal of the American Medical Directors Association, 6 (1), s. 68-75, available from: PM:15 871875 